\title{
Inspiration Exploring for Entrepreneurs through Case Analysis on the Development of the Big Issue
}

\author{
Shihan Lin \\ The international College of Xiamen University, China
}

Copyright $\bigcirc 2017$ by authors, all rights reserved. Authors agree that this article remains permanently open access under the terms of the Creative Commons Attribution License 4.0 International License

\begin{abstract}
This paper concerns the analysis of the development of The Big Issue magazine and its founder called John Bird. Discussing why and how The Big Issue succeeds from the internal and exterior factors in terms of the personality of John Bird, the supporting power, and how John Bird fits with the traditional notion of entrepreneurship. What is more, the aim of analyzing the development of The Big Issue is to give entrepreneurs inspiration on starting a new business.
\end{abstract}

Keywords Entrepreneurship, the Big Issue, Factors

\section{Background}

The big issue is a great social business which is widely circulated all round the world, its aim is to provide opportunity for homeless people or potential homelessness to earn a living and reintegrate into the society. "The Big Issue is the most prominent example of social entrepreneurship in the UK" (Hibbert et al, 2002: 288) [1]. John Bird launched The Big Issue in London in 1991 because Gordon Roddick of the Body Shop suggested to John Bird to set up a paper in Britain similar to the Street News of USA after Gordon Roddick visited New York and found the homeless people were helped in the New York (Hanks and Swithinbank, 1997: 149) [4]. The Big Issue is a magazine, which has a distinct approach to the problem of homelessness and is sold on the street by the homeless people in the UK (Hanks and Swithinbank, 1997: 149) [4]. It is a comprehensive magazine which combine news, campaigns and exposes with entertainment, films, music, and clubs ( Hanks and Swithinbank, 1997: 150) [4]. The main mission of The Big Issue magazine is to enable homeless people to work and earn money (Hibbert et al, 2002: 288) [1]. "The core value of the Big Issue is to help the homeless by involving them in an empowering process, rather than simply providing them with free services as is typical of charities" (Hibbert et al, 2005: 160) [3]. With the development and the extension of the Big Issue, according to the initial goal, The Big Issue is getting stronger and stronger, which consists of The Big Issue foundation, The Big Issue invest, and The Big Issue Shop. The Big Issue Foundation is an independently funded registered charity founded in 1995, which works solely with The Big Issue vendors to support them in different areas such as employment, training, education and learning, health care, housing, and personal development, and help vendors to rebuild their better future. The Big Issue Invest is a "Social Merchant Bank" which extends the mission of The Big Issue to demolish poverty from social enterprises and charities across the UK. The Big Issue Shop was launched in 2016, which is a completely customized online shop which focuses on selling products with a social echo. Nowadays, the Big Issue is separated in different editions and produced in Wales, the North of England, London, South-West England and Scotland, the vendors could be homeless, ex-homeless or vulnerably accommodated people who are in the age of 16 years or above (Hibbert et al, 2005: 160) [3]. By the year of 2017, The Big Issue has extended its business to other nations and area such as Australia, France, Japan, Kenya, Korea, Malawi, Namibia, The Republic of Ireland, South Africa, Zambia, and Taiwan. Therefore, the development of the Big Issue could be analysed through the aspects of personality of the founder and the exterior factors such as financial supporting power.

\section{Internal Factors}

\subsection{Personality}

The personality of John Bird is the internal factor that contributes The Big Issue. First of all, trait of accepting suggestion from others of John Bird, and his spirit of opportunity seeking with the current market led The Big Issue produced. Bird (1993) described that The Big Issue is not a new idea, since the 1980s, the homeless and the jobless sold Street News on the streets in New York, the chairman of the Body Shop, Gordon Roddick, brought this idea of selling magazine by the homeless back to London (SITED IN SHURMER-SMITH, 2003: 154) [2]. "In Britain in the 1990s, 
due to a variety of circumstances, there was an increasing number of young people sleeping on the streets, especially in the cities" (Hanks and Swithinbank, 1997) [4], people who are unemployed could go into a begging life status, faced with such a poor environment and without the methods to solve this problem at that time, John Bird grasped this opportunity. According to Peter Drucker (1964), entrepreneurs are the persons who maximize opportunities (SITED IN Manuel, 2006: 3) [6], Robert Hisrich (1985) described, "Entrepreneurship is the process of creating something different with value by devoting the necessary time and effort" (SITED IN Manuel, 2006: 3) [6], from this two points, which shows John Bird fits with the traditional entrepreneurship notion. In addition, The Big Issue Shop which provides every product a "Social Echo" for consumer shows that the founder has very good insight on how to seize the needs and tastes of consumers in marketing. Therefore, opportunity seeking from living environment and idea of reference play crucial roles in The Big Issue. John Bird knows observing the problems of the current society whilst considering the methods of problem solving, which facilitate the development of The Big Issue.

\subsection{Management Behavior}

The Big Issue requires all vendors to sign a vendor contract before they start to selling The Big Issue, requirement contains a series of conduct, for example, an identification badge which is provided by The Big Issue should be worn by vendors when they sell magazines, vendors cannot ask for handout and donation, selling through knocking doors from one house to the other house is not allowed, vendors cannot drink alcohol take drug et., those standards not only regularize the behavior of The Big Issue, but also regulate the behavior of vendors, which help solve living problems of homelessness and steady society. "According to Drucker (1985), entrepreneurship consists on creation of a new market and a new customer, by applying management concepts and management techniques, standardizing the product, designing process and tools, and by basing training on the analysis of the work to be done and setting the standards it required" (Manuel, 2006: 6) [6]. Therefore, the excellent managing method is another key element on the successful development of The Big Issue.

\subsection{Innovation Spirit}

The innovation of John Bird promoted the development of the Big Issue. Generally speaking, innovation is the most unusual trait of entrepreneurs (Siropolis, 1997: 40) [12]. It seems like that the idea of The Big Issue is not the original idea from John Bird, however, Kirton (1976) declared that creativity is not always about owning original notions (SITED IN Kirby, 2003: 132) [7]. So the successful development of The Big Issue cannot be separated from the renovation idea of John Bird based on the "Street News" from New York. Though the inspiration of The Big Issue is from the paper in New York, the Big Issue was the first firm to solve the problem of homeless people at that time in the UK, which still presents the innovative trait of John Bird. Skoll (2008) described that social entrepreneurs are those practical dreamers, who have the capability, the skill, and the vision to solve the problems and to make the world for the better (SITED IN Nicholls, 2008: v) [5]. John Bird knows how to make a breakthrough from the original idea of "Street News", develops business which fits in the society needs through analyzing the current society and potential market. Therefore, from the aspect of innovation of John Bird, it presents he fits with the traditional notion of entrepreneurship.

\subsection{Decision-Making Spirit}

What is more, there is a mutual action between innovation spirit and decision-making spirit. John Bird's ability of good decision-making with the current market promoted the development of The Big Issue. Bird (1993) mentioned that the first problem The Big Issue faced was the contents of this magazine, because it was not a logical idea if public did not want to buy a magazine only simply be about homelessness, and if there were not a large enough readership which meant no income for the homeless, in order to make it work as an excellent read as well as a social read, the arts pages were expanded, personality interviews were put in this magazine (SITED IN SHURMER-SMITH, 2003: 154) [2]. "It is assumed that decisions are based on preferences (wants, needs, interests, etc) and expectations of outcomes associated with alternative actions" (Chell, 2001: 114) [8]. "The potential and ability of a venture to become a market leader and capture a substantial portion of the overall market are significant contributing factors to the firm becoming a high-growth venture" (Nieman et al, 2003: 79) [9]. Thus, making decisions form the point of view of market play a crucial role for the development of The Big Issue. As development of time, extension of The Big Issue and its succeeding development reflect the capability of decision-making from John Bird. In order to offer more opportunities for vendors, after The Big Issue was founded in 1991, John Bird enlarged this business diffusion lines of The Big Issue Foundation, The Big Issue Invest, and The Big Issue Shop gradually in 1995, 2005 and 2016, which reflects the rational decision-making of John Bird according to catering to the development of our society, also it embodies the innovation spirit representing on decision-making. The Big Issue magazine has helped over 92,000 vendors earn $£ 115$ million since 1991, There are currently around 1500 vendors, and in the year of 2016, The Big Issue helped vendors to earn a total of $£ 5.5$ million. Nowadays, the magazine is read by an estimated 379,195 people across the UK and circulates 82,294 copies every week. Big Issue Invest offers social enterprises, charities and profit-withpurpose businesses, loans and investment from $£ 20,000$ to $£ 3$ 
million. As of 2005, they have invested in approximately 300 social enterprises and charities, all of which have positively influenced the lives of an estimated 1 million people across the UK. With the UK Social Bond Fund, in partnership with Columbia Threadneedle, The Big Issue Invest is seeking to make social investment become a mainstream. This is the first social investment fund offering daily liquidity and has raised over $£ 100$ million since January 2017 . The Big Issue sold its 200 millionth copy, celebrated its 25th anniversary and launched the online The Big Issue Shop by 2016 (www.bigissue.com/about/, last updated in 2017) [14]. all these good results of decision-making on building The Big Issue Foundation, The Big Issue Invest, and The Big Issue Shop fit in the needs of vendors and current market, which are the main factor to keep The Big Issue running stronger and better sustainably.

\subsection{Risk-Taking Spirit}

Lastly, the trait of risk-taking and risks evaluation promotes the development of a business, every business exists potential possibility of failure, only seize the opportunity of creating a business cannot lead to success, a core factor of leading to a successful business is knowing how to solve problems when face with depression. The phenomenon of temporary recession of the Big Issue shows John Bird's abilities of risk undertaking and problem-solving. Recent research on John Birds (growing business, 2008) [10] has shown that The Big Issue suffered from finance problem after six months it founded, faced with the property loss $£ 25,000$ a month, he had to make the publication to start making money, he got rid of around 10 persons then put the wages up to make staff work harder, He also changed this fortnightly magazine into a monthly magazine, and keeping the cost of the publication meanwhile doubled the price to the vendors, as a result, the magazine had turned a $£ 1,000$ profit. "At the extreme, entrepreneurial innovation introducing new products or services to a new market - is radical and risky" (Burns, 2007) [11], Thus, the growth of The Big Issue is inseparable from the spirit of risk undertaking and problem-solving of John Bird. "According to Longeneeker, Moore et al (1994), a common stereotype of the entrepreneur emphasizes such characteristics as high need for achievement, a willingness to take moderate risks, and a strong self-confidence" (Manuel, 2006: 4) [6], from the point of willingness to take moderate risks, it presents John Bird fits with the traditional notion of entrepreneurship, which is a core element led to The Big Issue success.

\section{Exterior Factors}

However, only the brilliant personality could not pave the successful way for the Big Issue, the exterior factors also play important role in Entrepreneurship. The opportunities from Gordon Roddick, the environment, and the support of the finance from the Body Shop constituted the successful elements for The Big Issue. One of the opportunities is the firsthand information from Gordon Roddick in New York. "Having seen a similar street paper in New York, Roddick tasked Bird with carrying out a feasibility study to see if could work in London" (growing business, 2008) [10], thus, the inspiration from Roddick was the producing cornerstone of The Big Issue. What's more, the environment of homelessness provided the best opportunity to found the Big Issue. In twentieth century, homelessness in Britain still presented its big problem (Hanks and Swithinbank, 1997: 149) [4], which presents the opportunity from the environment is an important factor for the development of The Big Issue. Furthermore, the Big Issue launched with capital from the Body Shop Foundation (Hanks and Swithinbank, 1997: 150) [4], which shows the finance support from body shop plays the important role. In addition, with the establish of The Big Issue Invest, social investment has been regarded as a precursory way to fund social businesses, charities and other ventures dealing with poverty and offering opportunity for people across the UK, The Big Issue Invest makes use of the power of financial investment to help grow the organisations tackling some of the most pressing social problems, in areas like job training, housing, mental health and financial inclusion (Editorial, 2016) [15]. Thus, the power of investor is one of the milestones for improving the development of The Big Issue. As a result, the Big issue might not be survived without the financial support. Lastly, the compassion of consumers presents a huge support for The Big Issue. References shows that consumers purchase the Big Issue magazine have two reasons, one is that they are into this magazine, the other is that they believe buying this magazine can help the homeless, which presents paying more than the magazine cover price (Hibbert et al, 2002: 288) [1]. What is more, "In recent years, two relevant and transcendental phenomena have emerged through the study of consumer behaviour: the leisure or entertainment sectors of shopping centres have undergone considerable changes and online shopping has undergone exponential growth" (Asuncion et al, 2017) [16]. There are many advantages of online shopping such as time saving, availability from everywhere, convenience, accessibility 24 hours per day, different kinds of products, and various options for consumers to compare products and brands (Hashim, 2015) [13].So faced with the growing of online shopping mode, the new addition called The Big Issue Shop joined in The Big Issue by 2016, online shopping is easily available for those people who are interested in the contents of The Big Issue or show sympathy for poverty, which enlarged the selling platform from street to home, this is also a method to improve the development of The Big Issue.

\section{Conclusions}

Above all, the success of The Big Issue is no accident. 
Both the internal factors of John Bird and the exterior factors from the environment surroundings compose the produce and the development of The Big Issue. The internal factors of John Bird cannot be separated from the exterior factors. Nowadays, "The concept of social entrepreneurship has attracted the recent interest of policy makers, with government departments and agencies declaring their support for this approach to alleviating social disadvantage" (Hibbert et al, 2002: 288) [1]. Although government provides more support to social entrepreneurship, as the development of current society, uncertain factors still exist in our daily life, risks and supports can not be estimated, the future development of The Big Issue still depends on a series of good traits of the founders, and the support from outside. Consequently, A good business should be built with creative ideas based on traditional notion, and improving constantly by catering to the development of society. To be an excellent successful entrepreneur, seeking opportunity, owning capability of managing methods, making a good decision with the current market, innovation, and the abilities of solving problems and undertake risks are the basic characters to found a good firm. Creation and renovation ideas of combining social issues and lateral thinking are the basic requirement for entrepreneurs. Using creation to solve social issues is useful for helping entrepreneurs to build a business. However, the main original goal of The Big Issue is to provide working opportunity for homelessness and finally improve their life quality, however only the format of The Big Issue Foundation really makes homeless people involve in jobs in person, the Big Issue Invest and the Big Issue Shop are just two different medium which raise funds for vendors of The Big Issue, as the development of technology and the magazine transition, though The Big Issue has been developed very good since when it was founded, there are still some potential risks and challenges for the development of the Big Issue, nowadays many publishers offer their magazines online, which threaten the industry of publication. "The magazine industry is making a transition towards digital media (Teresa,2010) [18]", and "The Internet has been referred to as a potentially disruptive technology for publishing industries (SITED IN Hanna-Kaisa, 2006 ) " [17], from these views, The Big Issue magazine should face with the risk of its extinction potentially. On the other hand, through a recent discussion about the reading behavior changing on the Internet, Nicholas Carr claimed that the web reader has become great at skimming contents but lost the ability of focusing, reading and thinking deeply (SITED IN Teresa, 2010) [18], which shows the necessity of existence of publication for those readers who prefer thinking deeply. Though in such situation, as digital reading platform emerging and developing, online magazine still could lead on the deduction of sales of The Big Issue magazine, therefore the depression of the Big Issue magazine could cause more and more the Big Issue vendors lose their job. As a result, to be an excellent entrepreneur, analyzing potential risks well-rounded from a successful industry is also a required skill. How the Big Issue still could go on developing well in the future would be a challenge for its founder and an entrepreneur starter.

\section{REFERENCES}

[1] Hibbert, S. A., Hogg, G., and Quinn, T. (2002). Consumer response to social entrepreneurship: The case of the Big Issue in Scotland. International Journal of Nonprofit and Voluntary Sector Marketing. Vol.7, No.3 pp.288-301

[2] Shurmer-smith, P. (2003). Doing Cultural Geography. Great Britain: The Cromwell Press Ltd.

[3] Hibbert, S.A, Hogg, G. and Quinn, T (2005). Social entrepreneurship: Understanding consumer motives for buying The Big Issue. Journal of Consumer Behaviour. Vol.4, 3, 159-172. Pp: 159-172

[4] Hanks, S. and Swithinbank, T. (1997). The Big Issue and other street papers: a response to homelessness. Journal of Enviroment and Urbanization. Vol, 9 No.1. Pp: 149-158

[5] Nicholls, A. (2008). Social Entrepreneurship. Oxford: Oxford university press.

[6] Manuel, E. G. (2006) Entrepreneurship and Economics. Available at SSRN: http://ssrn.com/abstract $=912762$ or http://dx.doi.org/10.2139/ssrn.912762

[7] Kirby, D. A. (2003) Entrepreneurship. New York: McGraw-Hill Education.

[8] Chell, E (2001) Entrepreneurship: globalization, innovation and development. Singapore: Seng Lee Press Ltd.

[9] Nieman, G., Hough, J. Nieuwenhuizen, C. (2003). Entrepreneurship, a south African perspective. Pretoria: Van Schaik Publishers.

[10] Growing Business, 2008. The Big Issue founder on social enterprise, second chances and why we need more risk-takers. [online] Available at $<$ http://www.growingbusiness.co.uk/john-bird.html?page=2> accessed [7 March 2013].

[11] Burns, P. (2007). Entrepreneurship and Small Business. 2nd Ed. New York: Palgrave Macmillan

[12] Siropolis, N. C. (1997). Small Business Management. Houghton Mifflin College Div

[13] Hashim S. (2015) Online Shopping Behavior. [J/OL] Available at $<$ http://uu.diva-portal.org/smash/record.jsf?pid=diva2\%3A85 $3275 \&$ dswid $=-3416 \#$ sthash.lspiqiDN.dpbs $>$ accessed [15-09-2015].

[14] The Big Issue. [EB/OL] https://www.bigissue.com/about/

[15] Editorial. (2016) Big Issue Invest: A recipe for success. [EB/OL] Available at $<$ https://www.bigissue.com/news/big-issue-invest-recipe-succ ess/ $>$ accessed [October 18, 2016]. 
[16] Asuncion, D., Mar, G., Arturo, M. (2017). Journal of Retailing and Consumer Services. Vol.38. Pp: 44-50
[17] Hanna-Kaisa, E. (2006). FRONTIERS OF E-BUSINESS RESEARCH

[18] Teresa, R. (2010). The Future of the Digital Magazine. URL: www.kth.se/csc 